\title{
IMPLEMENTASI KEWENANGAN BADAN PERMUSYAWARATAN DESA (BPD) DALAM MENJALANKAN FUNGSI PENGAWASAN TERHADAP PEMERINTAH DESA (STUDI DI KABUPATEN KUNINGAN)
}

\author{
Tarsim dan Erga Yuhandra \\ Fakultas Hukum Universitas Kuningan, Kuningan, Indonesia \\ E-mail: tarsimulis11878@gmail.com
}

Sitasi : Tarsim, Tarsim., \& Erga Yuhandra. Implementasi Kewenangan Badan Permusyawaratan Desa (BPD) Dalam Menjalankan Fungsi Pengawasan Terhadap Pemerintah Desa (Studi di Kabuapten Kuningan). UNIFIKASI : Jurnal I/mu Hukum, 5.1 (2018), 1-14. DOI : https://doi.org/10.25134/unifikasi.v5i1.759

Naskah diterima : 8-12-2017 Naskah direvisi : 23-1-2018

Naskah disetujui : 10-2-2018

\begin{abstract}
Abstrak : Reformasi dan otonomi daerah sebenarnya adalah harapan baru bagi pemerintah dan masyarakat desa untuk membangun desanya sesuai kebutuhan dan aspirasi masyarakat. Kewenangan Badan Permusyawaratan Desa (BPD) dalam melaksanakan fungsi pengawasan kepada pemerintah desa. Tujuan penelitian adalah untuk mengetahui kewenangan BPD dalam melaksanakan fungsi pengawasan sesuai Undang-undang Nomor 6 Tahun 2014 tentang Desa dan fakor-faktor yang menjadi kendala Badan Permusyawaratan Desa dalam melaksanakan fungsi pengawasan kepada pemerintah desa di Desa Sukaharja, Kecamatan Cibingbin, Kabupaten Kuningan. Metode penelitian ini dengan pendekatan yuridis empiris, yaitu menggunakan data primer dan sekunder dan dianalisis dengan metode deskriptif analisis. Hasil penelitian ini adalah kewenangan Badan Permusyawaratan Desa dalam melaksanakan fungsi pengawasan sesuai dengan Undang-undang Nomor 6 Tahun 2014 yaitu BPD memiliki hak untuk mengawasi dan meminta informasi tentang administrasi desa kepada pemerintah desa; menyampaikan pendapat tentang pelaksanaan pemerintahan desa, pelaksanaan pembangunan desa, pengembangan masyarakat desa, dan pemberdayaan masyarakat pedesaan; serta mendapatkan biaya operasional untuk pelaksanaan tugas dan fungsi anggaran pendapatan dan belanja desa serta faktor-faktor yang menjadi kendala yaitu dalam menerapkan fungsi supervisi kepada pemerintah desa terbagi menjadi 2 (dua) : faktor internal termasuk: sarana yang tidak memadai, pola komunikasi tidak berjalan dengan baik, dan anggota BPD tidak mengerti fungsi sedangkan faktor eksternal meliputi: masyarakat tidak mengerti fungsi BPD, ada sosialisasi pemerintah desa terkait fungsi Badan Permusyawaratan Desa, dan faktor sumber daya manusia masyarakat desa. Kesimpulan adalah kewenangan BPD dalam melaksanakan fungsi pengawasan sesuai Undang-Undang Nomor 6 Tahun 2014 tentang Desa yaitu BPD yang berhak mendapat pertanggungjawaban kepala desa dan meminta informasi kepada pemerintah desa.
\end{abstract}

Kata kunci: otoritas, bpd, pengawasan, dan pemerintahan desa.

\section{THE IMPLEMENTATION OF AUTHORITY OF VILLAGE CONSULTATIVE AGENCY IN RUNNING CONTROL FUNCTIONS ON VILLAGE GOVERNMENT (STUDY IN KUNINGAN REGENCY)}

\begin{abstract}
The writer conducted this research with background to know the authority of Village Consultative Agency (Badan Permusyawaratan Desa) in implementing supervision function to village government. The purposes of writing this research are to know the authority of Village Consultative Agency in implementing supervision function according to Law Number 6 of 2014 about Village and what factors that become obstacles are faced by Village Consultative Agency in implementing supervision function to village government in Sukaharja Village, Cibingbin District, Kuningan Regency. This research used descriptive analysis research with juridical-normative approach. Stage of research is through literature research using primary and secondary data collected through documentation and analyzed descriptive qualitative method. The result of this research was the authority of Village Consultative Agency in implementing supervisory function according to Law Number 6 of 2014 namely VCB has the right to supervise and request information about the administration of village administration to village government; to express opinions on the implementation of village governance, implementation of village development, village community development, and empowerment of rural communities; as well as obtaining operational costs for the execution of duties and functions of the village income and expenditure budget. The factors that into two: internal factor including: inadequate means, communication patterns were not working properly, and members of Village Consultative Agency do not understand the functions while external factors include: the community does not understand the functions of Village Consultative Agency, there was a socialization of the village government related to the function of Village Consultative Agency, and the human resource factor of the village community. The conclusion of paper was the authority of Village Consultative Agency in implementing supervision function according to Law Number 6 of 2014 about Village namely VCB was entitled to hold accountability of village head and ask for information to village government.
\end{abstract}

Keywords: authority, vcb, supervision, and village government. 
UNIFIKASI : Jurnal IImu Hukum, Volume 05 Nomor 01, Januari 2018
p-ISSN 2354-5976, e-ISSN 2580-7382

https://journal.uniku.ac.id/index.php/unifikasi

\section{PENDAHULUAN}

Reformasi dan otonomi daerah sebenarnya adalah harapan baru bagi pemerintah dan masyarakat desa untuk membangun desanya sesuai kebutuhan dan aspirasi masyarakat. Bagi sebagian besar aparat pemerintah desa, otonomi adalah suatu peluang baru yang dapat membuka ruang kreatifitas bagi aparatur desa dalam mengelola desa, misalnya semua hal yang akan dilakukan oleh pemerintah desa harus melalui rute persetujuan kecamatan, untuk sekarang hal itu tidak berlaku lagi. ${ }^{1}$ Hal ini jelas membuat pemerintah desa semakin leluasa dalam menentukan program pembangunan yang akan dilaksanakan, dan dapat disesuaikan dengan kebutuhan masyarakat desa.

Dalam pemerataan pembangunan di desa, pemerintah melibatkan partisipasi masyarakat untuk menumbuhkan kesadaran bahwa pada dasarnya pembangunan desa menggunakan prinsip dilakukan oleh masyarakat dan untuk masyarakat ${ }^{2}$. Kesadaran masyarakat ini akan menimbulkan rasa memiliki dan tanggung jawab tinggi dalam pembangunan desa. Pembangunan desa pada akhirnya akan dirasakan oleh masyarakat, sehingga partisipasi masyarakat bisa menuntun desa ke arah yang lebih baik dengan pembinaan dari pemerintah daerah yang akan berdampak positif bagi pembangunan desa.

Dalam Pasal 54 Undang-Undang Nomor 6 Tahun 2014 tentang Desa dijelaskan bahwa musyawarah desa merupakan forum permusyawaratan yang diikuti oleh badan

Karlos Mangoto, "Fungsi Badan Permusyawaratan Desa (BPD) dalam Pengawasan Penyelenggaraan Pemerintahan di Lesah Kecamatan Tagulandang Kabupaten Kepulauan Sitaro", Jurnal, Perpustakaan FISIP UNSRAT Manado, 2016, hlm. 1-2.

2 Ibid., hlm. 2.
Permusyawaratan Desa, Pemerintah Desa, dan unsur masyarakat desa yang bertujuan untuk memusyawarakan hal yang bersifat strategis dalam penyelenggaraan pemerintah desa. Berkaitan dengan penyelenggara pemerintah desa dan menggerakan masyarakat untuk berpartisipasi dalam pembangunan fisik desa dan penyelenggaraan administrasi desa, maka setiap keputusan yang diambil harus berdasarkan atas musyawarah desa untuk mencapai keputusan bersama.

Pemerintah Desa sangat berperan penting dalam pembangunan desa dalam hal ini kepala desa beserta jajaranya diberikan wewenang untuk mengurus wilayahnya. Dalam Peraturan Pemerintah (PP) Nomor 43 Tahun 2014 tentang Peraturan Pelaksana Undang-undang Nomor 6 Tahun 2014, dijelaskan bahwa Desa memiliki organisasi pemerintahan sendiri, yaitu kepala desa beserta perangkat desa. Kepala desa merupakan pimpinan pemerintah desa yang dibantu oleh perangkat desa sebagai unsur pembantu kepala desa.

Berdasarkan Peraturan Daerah Kabupaten Kuningan Nomor 11 Tahun 2015 tentang Susunan Organisasi dan Tata Kerja Pemerintahan Desa dijelaskan bahwa pemerintah desa mempunyai tugas dan fungsi mengatur dan menyelenggarakan pemerintahan desa berdasarkan kebijakan yang ditetapkan bersama BPD. Pemerintah Desa dapat membentuk lembaga kemasyarakatan dan mempunyai tugas menyelenggarakan kegiatan pemerintahan dan urusan pemerintahan umum. Kepala desa memiliki tugas untuk menyelenggarakan pemerintahan desa, melaksanakan pembangunan desa, pembinaan kemasyarakatan, dan pemberdayaan desa. Dalam menyelenggarakan tugas dan fungsinya, kepala desa bertanggungjawab 
UNIFIKASI : Jurnal IImu Hukum, Volume 05 Nomor 01, Januari 2018

kepada Bupati melalui Camat, memberikan keterangan pertanggungjawaban kepada BPD sekurang-kurangnya satu kali setahun.

Dalam Pasal 61 ayat (2) Undang-Undang Nomor 6 Tahun 2014 dijelaskan bahwa Badan Permusyawaratan Desa (BPD) merupakan lembaga perwujudan demokrasi dalam penyelenggaraan pemerintah desa yang berfungsi menampung dan menyalurkan aspirasi masyarakat, menampung aspirasi masyarakat, BPD melaksanakan tugas pengawasan kinerja kepala desa, serta bersama-sama dengan kepala desa membahas dan menyepakati Rancangan Peraturan Desa (PerDes). Berdasarkan Peraturan Daerah Kabupaten Kuningan Nomor 11 Tahun 2015 tentang Susunan Organisasi dan Tata Kerja Pemerintahan Desa dijelaskan bahwa Badan Permusyawaratan Desa adalah lembaga yang melaksanakan fungsi pemerintahan yang anggotanya merupakan wakil dari penduduk desa berdasarkan keterwakilan wilayah dan ditetapkan secara demokratis.

BPD memiliki tugas bersama dengan kepala desa untuk merencanakan dan menetapkan kebijakan dalam melaksanakan pemerintahan dan pembangunan desa. BPD juga adalah perwakilan masyarakat dalam hal ini dapat berpartisipasi dalam pengawasan penyelenggaraan pembangunan serta pemerintahan desa. ${ }^{3}$ Selain itu BPD juga berkewajiban untuk memperlancar pelaksanaan tugas kepala desa. BPD dan Kepala Desa perlu meningkatkan pelaksaan koordinasi guna mewujudkan kerjasama yang baik dalam proses pembangunan di desa.

Undang-Undang Nomor 23 Tahun 2014 tentang Pemerintahan Daerah telah memberikan berbagai perubahan ke arah

Sartika Putri Ngadi, "Peran Badan Permusyawaratan Desa dalam Menjalankan Fungsi Pengawasan Pemerintahan di Desa Lopana Kecamatan Amurang Timur Kabupaten Minahasa Selatan", Jurnal, Perpustakaan FISIP UNSRAT Manado, 2013, hlm. 1.
p-ISSN 2354-5976, e-ISSN 2580-7382

https://journal.uniku.ac.id/index.php/unifikasi

peningkatan kesejahteraan kepada masyarakat melalui pelayanan yang baik, serta kinerja yang maksimal secara langsung dan transparan. Dengan adanya otonomi daerah ini pemerintah daerah dapat lebih memperhatikan daerah terpencil dalam rangka pemerataan pembangunan. Peningkatan kesejahteraan di daerah secara langsung dilakukan dengan cara pemerataan pembangunan seperti di bidang pendidikan dan pertanian, khususnya di desa yang tepat sasaran akan menumbuhkan tingkat partisipasi masyarakat. Badan Permusyawaratan Desa memiliki tiga fungsi yaitu legislasi, pengawasan, dan menampung aspirasi masyarakat. ${ }^{4}$ Masyarakat sebagai bagian dalam pembangunan mempunyai hak untuk berpastrisipasi dalam meningkatkan kinerja pemerintah ${ }^{5}$

BPD sebagai badan permusyawaratan yang anggotanya berasal dari masyarakat desa tersebut dan dipilih secara demokratis. Disamping menjalankan fungsinya sebagai tempat yang menghubungkan, antara Kepala Desa dengan masyarakat. 6 Dengan adanya BPD diharapkan penyampaian aspirasi masyarakat dalam melaksanakan tugas pengawasan pembangunan fisik desa yang selaras dengan kebijakan kepala desa dalam pelaksanaan tugas. Dalam hal ini tugas BPD adalah mengawasi penyelenggaraan pembangunan fisik desa yang dikelola oleh kepala desa selaku pemerintah desa.

Telah begitu banyak peraturan yang mengatur tentang Badan Permusyawaratan

\footnotetext{
4 Erga Yuhandra, Kewenangan BPD (Badan Permusyawaratan Desa) Dalam Menjalankan Fungsi Legislasi, Jurnal Unifikasi, ISSN 2354-5976 Vol. 3 No. 2 Juli 2016. Halaman. 61-76.

5 Suwari Akhmaddhian dan Anthon Fathanudien, Partisipasi Masyarakat dalam Mewujudkan Kuningan sebagai Kabupaten Konservasi (Studi di Kabupaten Kuningan), Jurnal UNIFIKASI Vol. 2 (1), 2015. Kuningan : FH UNIKU. hlm.86-97

6 Ibid., hlm. 2.
} 
UNIFIKASI : Jurnal IImu Hukum, Volume 05 Nomor 01, Januari 2018

Desa (BPD) tanpa implementasi yang jelas menjadikan penulis tertarik untuk mengetahui bagaimana sebenarnya kinerja BPD itu, apakah benar-benar membantu pemerintah desa dalam penyelenggaraan pemerintahan atau hanya menjadi simbol demokrasi tanpa implementasi, atau malah menimbulkan masalah yang tidak perlu, yang hanya akan menghabiskan energi yang sesungguhnya lebih dibutuhkan oleh masyarakat desa untuk melepaskan diri dari jerat kemiskinan dan krisis ekonomi. Pemerintah desa perlu meningkatkan kesadaram masyarakat maka diperlukan inovasi-inovasi untuk peningkatan kesadaran masyarakat melalui peningkatan peran-peran organisasi di desa. ${ }^{7}$

\section{RUMUSAN MASALAH}

Adapun yang menjadi pokok permasalahan yang akan menjadi fokus perhatian utama yang akan dibahas dalam penulisan ini yaitu Bagaimana kewenangan Badan Permusyawaratan Desa dalam menjalankan fungsi pengawasan berdasarkan Undang-Undang Nomor 6 Tahun 2014 tentang Desa? Faktor-faktor apa saja yang menjadi penghambat dalam menjalankan fungsi pengawasan Badan Permusyawaratan Desa terhadap Pemerintah Desa di Desa Sukaharja Kecamatan Cibingbin Kabupaten Kuningan?

\section{METODE PENELITIAN}

Penelitian ini menggunakan penelitian deskriptif-analisis dengan pendekatan yuridis-normatif. Penelitian dilaksanakan melalui satu tahap: penelitian kepustakaan. Data penelitian meliputi data primer dan data sekunder dengan teknik pengumpulan data

\footnotetext{
${ }^{7}$ Suwari Akhmaddhian, Pengaruh Kebijakan Pemerintah Daerah Dalam Konservasi Sumber Daya Air Terhadap Kesadaran Lingkungan Masyarakat Kabupaten Kuningan, Jurnal Unifikasi, ISSN 2354-5976 Vol. 04 Nomor 01 Januari 2017, hlm. 1-13.
}

p-ISSN 2354-5976, e-ISSN 2580-7382 https://journal.uniku.ac.id/index.php/unifikasi

berupa teknik dokumentasi. Alat pengumpul data yaitu dokumentasi dengan analisis data dilakukan menggunakan metode deskriptif kualitatif. Bahan hukum primer yaitu UndangUndang Dasar Negara Republik Indonesia Tahun 1945, Undang-Undang Nomor 9 Tahun 2015 tentang Perubahan Kedua atas UndangUndang Nomor 23 Tahun 2014 tentang Pemerintahan Daerah, Undang-Undang Republik Indonesia Nomor 6 Tahun 2014 tentang Desa, Peraturan Pemerintah Nomor 72 Tahun 2005 tentang Desa, Peraturan Daerah Kabupaten Kuningan Nomor 11 Tahun 2015 tentang Susunan Organisasi dan Tata Kerja Pemerintahan Desa.

\section{PEMBAHASAN}

Kewenangan BPD Menjalankan Fungsi Pengawasan Berdasarkan Undang-Undang Nomor 6 Tahun 2014 Pasal 1 ayat (3) UndangUndang Dasar Negara Republik Indonesia Tahun 1945 amandemen ketiga menyatakan bahwa Negara Indonesia adalah Negara Hukum. Hal ini menunjukkan bahwa tindakan pemerintah ataupun rakyat harus sesuai berdasarkan hukum. Berdasarkan Pasal 18 ayat (5) Undang-Undang Dasar Negara Republik Indonesia Tahun 1945 menyatakan bahwa "Pemerintah Daerah menjalankan otonomi seluas-luasnya, kecuali urusan pemerintah yang oleh undang-undang ditentukan sebagai urusan pemerintah pusat.

Sebagai implementasi dari amanat pasal di atas maka disahkanlah Undang-Undang Nomor 9 Tahun 2015 tentang Perubahan Kedua atas Undang-Undang Nomor 23 Tahun 2014 tentang Pemerintahan Daerah, dalam undang-undang tersebut menyatakan bahwa otonomi daerah adalah hak, wewenang, dan kewajiban daerah otonom untuk mengatur dan mengurus sendiri urusan pemerintahan dan kepentingan masyarakat setempat dalam sistem Negara Kesatuan Republik Indonesia 
UNIFIKASI : Jurnal IImu Hukum, Volume 05 Nomor 01, Januari 2018

(NKRI). Dalam Undang-Undang Nomor 9 Tahun 2015 tentang Perubahan Kedua atas Undang-Undang Nomor 23 Tahun 2014 tentang Pemerintah Daerah dikenal beberapa asas yang berkaitan dengan otonomi daerah yaitu: asas desentralisasi, asas dekonsentrasi, dan tugas pembantuan.

Demokrasi sebagai suatu sistem telah dijadikan alternatif dalam berbagai tatanan aktifitas masyarakat dan bernegara di beberapa negara. Gagasan pokok atau gagasan dasar suatu pemerintahan demokrasi adalah pengakuan hakikat manusia, yaitu pada dasarnya manusia mempunyai kemampuan yang sama dalam hubungan sosial. Demokrasi diyakini dapat melindungi kebabasan rakyat dengan memberikan tugas kepada pemerintah untuk melindugi rakyat. Apabila demokrasi dijunjung tinggi, rakyat dapat menikmati kebabasan mereka sebagai pemegang kedaulatan.

Kata kewenangan berasal dari kata dasar wenang yang diartikan sebagai hal berwenang, hak dan kekuasaaan yang dipunyai untuk melakukan sesuatu. Kewenangan yang dimiliki oleh organ (institusi) pemerintahan dalam melakukan perbuatan nyata (riil), mengadakan pengaturan atau mengeluarkan keputusan selalu dilandasi oleh kewenangan yang diperoleh dari konstitusi secara atribusi, delegasi, maupun mandat. Suatu atribusi menunjuk pada kewenangan yang asli atas dasar konstitusi (UUD). Pada kewenangan delegasi, harus ditegaskan suatu pelimpahan wewenang kepada organ pemerintahan yang lain. ${ }^{9}$

8 Bagus Pambudi, "Peran BPD dalam melaksanakan Fungsi Pengawasan Kepala Desa di Desa Sarimulyo Kecamatan Ngawen Kabupaten Blora", Jurnal Penelitian, Sumber: http://www.download.portalgaruda.org, diakses 22 Februari 2017.

9 Rusadi Kantaprawira, "Hukum dan Kekuasaan", Makalah, Universitas Islam Indonesia, Yogyakarta, 1998, hlm. 37-38.
p-ISSN 2354-5976, e-ISSN 2580-7382

https://journal.uniku.ac.id/index.php/unifikasi

Berdasarkan Pasal 55 Undang-Undang Nomor 6 Tahun 2014 tentang Desa dijelaskan bahwa Badan Permusyawaratan Desa mempunyai fungsi membahas dan menyepakati rancangan peraturan desa bersama kepala desa, menampung dan menyalurkan aspirasi masyarakat desa, dan melakukan pengawasan kinerja kepala desa. Ketentuan tersebut menggambarkan bahwa wewenang Badan Permusyawaratan Desa dalam jalannya pemerintahan adalah sebagai mitra kerja pemerintah desa yang khususnya dalam hal ini adalah pembuatan peraturan desa.

Peran BPD dalam mendukung tata penyelengaraan pemerintahan desa mencakup beberapa hal yaitu: fungsi dalam penyerapan aspirasi, fungsi pengayoman adat, fungsi menetapkan peraturan desa, dan fungsi pengawasan. Keempat fungsi tersebut dapat dijelaskan sebagai berikut:

a. Fungsi Penyerapan Aspirasi: aspirasi dari masyarakat yang diserap oleh BPD dilakukan melalui mekanisme atau cara yaitu: penyampaian langsung kepada BPD, penyampaian melalui forum warga dan penyampaian melalui pertemuan tingkat desa.

b. Fungsi Pengayoman Adat: adat adalah aturan, kebiasaan-kebiasaan yang tumbuh dan berbentuk dari suatu masyarakat atau daerah yang dianggap memiliki nilai yang dijunjung serta dipatuhi masyarakat pendukungnya. Adat juga merupakan norma yang tidak tertulis, namun sangat kuat mengikat sehingga anggota-anggota masyarakat yang melanggar adat istiadat akan menderita, karena sanksi keras yang kadang-kadang secara tidak langsung dikenakan.

c. Fungsi menetapkan Peraturan Desa: fungsi menetapkan peraturan desa yang dilakukan oleh BPD mengacu kepada 
UNIFIKASI : Jurnal IImu Hukum,

Volume 05 Nomor 01, Januari 2018

peraturan yang ada. BPD berfungsi menetapkan Peraturan Desa bersama Kepala Desa serta BPD berfungsi menampung dan menyalurkan aspirasi masyarakat bersama Kepala Desa.

d. Fungsi Pengawasan: pengawasan ialah suatu proses dimana pimpinan ingin mengetahui apakah hasil pelaksanaan pekerjaan yang dilakukan oleh bawahannya sesuai dengan rencana, perintah, tujuan dan kebijaksanaan yang telah ditentukan. Jelasnya pengawasan harus berpedoman pada rencana yang telah ditentukan, perintah, tujuan dan kebijaksanaan yang telah ditentukan sebelumnya. Pengawasan sebagai proses dalam menetapkan ukuran kinerja dan pengambilan tindakan yang dapat mendukung pencapaian hasil yang diharapkan sesuai dengan kinerja yang telah ditetapkan tersebut. Pengawasan sebagai suatu proses untuk menilai kesesuaian pekerjaan para anggota organisasi pada berbagai bidang dan bebagai tingakatan manajemen dengan program yang telah ditetapkan sebelumnya.

Dari uraian di atas maka dapat dijelaskan bahwa kewenangan Badan Permusyawaratan Desa (BPD) berdasarkan Undang-Undang Nomor 6 Tahun 2014 adalah sebagai mitra kerja pemerintah desa yang khususnya dalam hal ini adalah pembuatan peraturan desa. Selain itu, BPD juga berwenang dalam hal penyerapan aspirasi, pengayoman adat, dan pengawasan terhadap penyelenggaraan pemerintahan desa.

Faktor-faktor Penghambat Fungsi Pengawasan BPD terhadap Pemerintah Desa

a. Faktor-faktor Penghambat Fungsi Pengawasan Badan Permusyawaratan Desa terhadap Pemerintah Desa
p-ISSN 2354-5976, e-ISSN 2580-7382

https://journal.uniku.ac.id/index.php/unifikasi

Dalam menjalankan fungsi pengawasan BPD sebagai lembaga perwakilan masyarakat di tingkat desa, tentu terdapat berbagai hambatan-hambatan, sehingga dapat mempengaruhi BPD dalam menjalankan fungsinya yang belum secara maksimal dilakukan. Hambatan-hambatan anggota BPD dalam menjalankan fungsinya pengawasan penyelenggaraan pemerintahan desa secara umum terbagi menjadi dua jenis penghambat yaitu penghambat internal dan penghambat eksternal. Hasil temuan peneliti di Desa Sukaharja Kecamatan Cibingbin Kabupaten Kuningan, kedua jenis penghambat tersebut dapat dijelaskan pada uraian berikut:

1) Faktor Penghambat Internal

Faktor penghambat internal merupakan faktor-faktor yang menghambat fungsi pengawasan yang berasal dari Badan Permusyawaratan Desa (BPD) itu sendiri. Faktor penghambat internal BPD dalam menjalankan fungsi pengawasan terhadap pemerintahan desa antara lain:

a) Sarana Belum Memadai

Dalam melaksanakan tugasnya sebagai BPD sangat dibutuhkan wadah sebagai sekretariat yang digunakan dalam melakukan segala kegiatan yang berkenaan dengan kegiatan BPD mulai perencanaan dan pengadministrasian. Wadah atau tempat berupa kantor sangat dibutuhkan BDP demi terorganisasinya seluruh kegiatan BPD hal ini juga dimaksudkna untuk memudahkan jalur komunikasi dan koordinasi antara anggota BPD yang lain. Selain wadah atau kantor, untuk lancarnya segala kegiatan BPD juga dibutuhkan kendaraan operasional yang nantinya akan digunakan dalam upaya peningkatan kinerja BPD. Dua sarana tersebut sangat dibutuhkan BPD dalam melaksanakan tugas sebagai badan pengawasan pemerintah desa. 
UNIFIKASI : Jurnal IImu Hukum, Volume 05 Nomor 01, Januari 2018

b) Pola Komunikasi Tidak Berjalan Sebagaimana Mestinya

Pola komunikasi sangat mempengaruhi berjalannya fungsi Badan Permusyawaratan Desa (BPD) dengan melihat bagaimana hubungan emosional antara ketua BPD dengan para anggotanya seperti terlihat pada pola komunikasi yang dibangun selama ini. Melihat fakta yang terjadi di lapangan salah satu faktor penghambat implementasi fungsi dari Badan Permusyawaratan Desa (BPD) yaitu pola komunikasi tidak berjalan sebagaimana mestinya, baik antara ketua dengan anggotanya maupun antara anggota dengan anggota BPD lainnya. Hal ini terjadi karena kesibukan atau aktivitas sehari-hari dari ketua BPD dan anggota BPD yang bekerja pada organisasi/instansi lain atau memiliki usaha sendiri sehingga waktu untuk berkumpul minim dan pola komunikasi terjalin kurang intensif.

c) Anggota BPD Tidak Memahami Fungsi

Anggota BPD tidak memahami fungsinya sebagai anggota BPD berdasarkan peraturan daerah yang berlaku. Salah satu faktor penghambat implementasi fungsi dari BPD yaitu anggota BPD tidak memahami fungsinya sendiri, fakta yang ditemukan di lapangan bahwa ternyata anggota BPD tidak memahami fungsi sesuai yang ada dalam peraturan perundang-undangan yang berlaku. Pahaman mereka bahwa fungsi BPD hanya sekedar mitra kerja dimana apapun keputusan kepala desa, BPD harus mendukung penuh keputusan tersebut tanpa ada musyawarah/komunikasi sebelumnya kepala desa dengan BPD.

2) Faktor Penghambat Eksternal

Faktor penghambat eksternal merupakan faktor-faktor yang menghambat fungsi pengawasan yang berasal dari luar Badan Permusyawaratan Desa (BPD). Faktor penghambat eksternal BPD dalam menjalankan fungsi pengawasan terhadap
p-ISSN 2354-5976, e-ISSN 2580-7382

https://journal.uniku.ac.id/index.php/unifikasi

pemerintahan desa antara lain sebagai berikut:

a) Masyarakat Kurang Memahami Fungsi dari BPD

Mendengarkan aspirasi masyarakat merupakan salah satu fungsi BPD yang sangat penting. Apa yang dibutuhkan masyarakat harus tersampaikan kepada pemerintah desa. Disinilah peran BPD untuk mendengarkan aspirasi masyarakat begitupun masyarakat sangat diharapkan untuk menyampaikan aspirasinya. Namun yang terjadi di lapangan bukan hanya anggota BPD yang kurang memahami fungsi mereka tetapi masyarakat juga ternyata tidak paham sama sekali apa fungsi BPD itu. Jadi dalam pelaksanaan fungsi dalam hal mendengar dan menyalurkan aspirasi masyarakat tidak berjalan sebagaimna yang terdapat dalam undangundang.

b) Tidak Ada Sosialisasi dari Pemerintah Desa Terkait Fungsi BPD

Melihat dari dua faktor penghambat pelaksanaan fungsi BPD yaitu anggota BPD tidak memahami fungsinya sebagai anggota BPD berdasarkan peraturan daerah yang berlaku dan masyarakat kurang memahami fungsi dari BPD, maka dibutuhkan adanya sosialisasi fungsi Badan Permusyawaratan Desa (BPD) dari pemerintah desa maupun dari anggota BPD itu sendiri. Hal ini diharapkan agar memahami fungsinya masing-masing baik pemerintaha desa dan BPD maupun masyarakat itu sendiri. Namun yang terjadi di lapangan sosialisasi yang dimaksudkan ini tidak ada. Ini sangat dibutuhkan dalam melaksanakan tugas dan fungsinya sesuai dengan undang-undang yang berlaku.

c) Faktor Sumber Daya Manusia Masyarakat Desa

Faktor sumber daya manusia masyarakat desa yang mayoritas tamatan sekolah dasar turut mempengaruhi terhadap pelaksanaan 
UNIFIKASI : Jurnal IImu Hukum, Volume 05 Nomor 01, Januari 2018

fungsi pengawasan Badan Permusyawaratan Desa (BPD) terhadap pemerintah desa. Hal ini dikarenakan kurangnya pengetahuan dan wawasan masyarakat sehingga partisipasi masyarakat dalam mendukung fungsi pengawasan BPD terhadap pemerintah desa menjadi tidak maksimal.

Berdasarkan teori pengawasan bahwa fungsi pengawasan Badan Permusyawaratan Desa (BPD) terhadap pemerintah desa adalah sebagai pengontrol terhadap kekuasaan pemerintah desa. Fungsi pengawasan menjadi titik krusial penciptaan tata kepemerintahan yang baik (good goverment) karena mempersempit ruang terjadinya perubahan pemerintahan yang tercela yang frekuensinya lebih banyak terjadi dalam pemerintah. Diantara fungsi BPD (membahas dan menyepakati rancangan perdes, menampung dan menyalurkan aspirasi rakyat, melakukan pengawasan kinerja kepala desa) maka fungsi kontrol/pengawasan merupakan fungsi BPD yang sampai saat ini merupakan chekc and balance yang dibutuhkan bagi penyelenggara pemerintah yang baik (good goverment).

Pengawasan adalah suatu penilaian yang merupakan suatu proses pengukuran dan verifikasi dari serangkaian dari proses yang telah diselenggarakan secara berkelanjutan. Pada dimensi ini, ada ukuran yang telah dicapai dan menjadi dasar untuk langkah selanjutnya. Oleh karena itu, dalam dimensi pengawasan ada unsur pengendalian. Pengendalian ditujukan secara langsung dengan memberikan arah kepada objek yang dikendalikan, atau dapat disebut sektor tertentu dari kegiatan yang diselenggarakan berdasarkan pengorganisasian manajemen yang sudah ditentukan. ${ }^{10}$

10 Prayudi Atmosudirdjo, Hukum Administrasi Negara, Ghalia Indonesia, Jakarta, 1992, hlm. 86.
p-ISSN 2354-5976, e-ISSN 2580-7382

https://journal.uniku.ac.id/index.php/unifikasi

b. Kewenangan BPD dalam Menjalankan Fungsi Pengawasan Berdasarkan UndangUndang Nomor 6 Tahun 2014 Tentang Desa.

Pengawasan ialah suatu proses dimana pimpinan ingin mengetahui apakah hasil pelaksanaan pekerjaan yang dilakukan oleh bawahannya sesuai dengan rencana, perintah, tujuan dan kebijaksanaan yang telah ditentukan. Jelasnya pengawasan harus berpedoman pada rencana yang telah ditentukan, perintah, tujuan dan kebijaksanaan yang telah ditentukan sebelumnya. Pengawasan sebagai proses dalam menetapkan ukuran kinerja dan pengambilan tindakan yang dapat mendukung pencapaian hasil yang diharapkan sesuai dengan kinerja yang telah ditetapkan tersebut.

Pengawasan dapat dilakukan setiap saat, baik terhadap perencanaan dan kegiatan pelaksanaannya, selama proses manajemen maupun administrasi berlangsung atau setelah berakhir untuk mengetahui tingkat pencapaian tujuan suatu organisasi atau kerja. Pengawasan administrasi merupakan penataan pelaksanaan seluruh aktifitas dalam bagi seluruh kelembagaan agar tercipta keteraturan. Tujuan pengawasan adminstratif dalam kelembagaan khususnya bagi kelembagaan publik agar pendataan dan pembagian atau pendistribusian suatu kegiatan atau pekerjaan dilakukan dengan berdasarkan kepada keadilan dan sesuai dengan kemampuan masing-masing anggota kelembagaan. ${ }^{11}$

Pengawasan dalam proses manajemen/administrasi dimaksudkan untuk mengetahui tingkat keberhasilan dan kegagalan yang terjadi setelah perencanaan

11 H. Makmur, Efektifitas Kebijakan Kelembagaan Pengawasan, Refika Aditama, Bandung, 2011, hlm. 186-187. 
UNIFIKASI : Jurnal IImu Hukum, Volume 05 Nomor 01, Januari 2018

dibuat dan dilaksanakan. Keberhasilan perlu dipertahankan dan ditingkatkan dalam perwujudan manajemen/administrasi dilingkungan suatu organisasi atau unit kerja tertentu. Sebaliknya, setiap kegagalan harus diperbaiki dengan menghindari penyebabnya baik dalam menyusun perencananaan dan pelaksanaannya. Oleh karena itu, pengawasan dilakukan agar mendapatkan umpan balik (feed back) untuk melaksanakan perbaikan jika terdapat kekeliruan atau penyimpangan sebelum menjadi lebih buruk dan sulit diperbaiki. $^{12}$

Untuk menghindari kemungkinan adanya penyimpangan atau penyelewengan oleh pemerintahan desa maka pengawasan oleh BPD merupakan suatu hal yang mutlak harus ada, karena dalam sistem representatif goverment pengawasan merupakan kekuasaan asli (original power) lembaga legislasi. Oleh karena itu, sesungguhnya BPD lebih befungsi sebagai pengontrol terhadap kekuasaan pemerintah desa. Fungsi pengawasan menjadi titik krusial penciptaan tata kepemerintahan yang baik (good goverment) karena mempersempit ruang terjadinya perubahan pemerintahan yang tercela yang frekuensinya lebih banyak terjadi dalam pemerintah. Diantara tiga fungsi BPD (membahas dan menyepakati rancangan perdes, menampung dan menyalurkan aspirasi rakyat, melakukan pengawasan kinerja kepala desa) maka fungsi kontrol/pengawasan merupakan fungsi BPD yang sampai saat ini merupakan chekc and balance yang dibutuhkan bagi penyelenggara pemerintah yang baik (good goverment).

Kewenangan Badan Permusyawaratan Desa (BPD) dalam menjalankan fungsi

12 Mohammad Fiqqri Fajar Nugroho, "Pengawasan Badan Permusyawaratan Desa dalam Perencanaan Pembangunan Desa di Kecamatan Margoyoso Kabupaten Pati", Skripsi, Fakultas Syari'ah dan Hukum Universitas Islam Negeri Sunan Kalijaga Yogyakarta, 2016, hlm. 21.
p-ISSN 2354-5976, e-ISSN 2580-7382

https://journal.uniku.ac.id/index.php/unifikasi

pengawasan berdasarkan Undang-Undang Nomor 6 Tahun 2014 yaitu BPD berhak mengawasi dan meminta keterangan tentang penyelenggaraan pemerintahan desa kepada pemerintah desa, menyatakan pendapat atas penyelenggaraan pemerintahan desa, pelaksanaan pembangunan desa, pembinaan kemasyarakatan desa, dan pemberdayaan masyarakat desa, serta mendapatkan biaya operasional pelaksanaan tugas dan fungsinya dari Anggaran Pendapatan dan Belanja Desa (APBDes).

Berdasarkan ketentuan tersebut maka BPD mempunyai fungsi membuat dan menetapkan peraturan desa bersama-sama dengan pemerintah desa. Selain itu, BPD juga berfungsi mengawasi jalannya pemerintah desa. Fungsi dalam bidang pengawasan ini meliputi pengawasan terhadap pelaksanaan peraturan desa, pengawasan terhadap Anggaran Pendapatan dan Belanja Desa (APBDes), dan pengawasan terhadap keputusan kepala desa. Dalam pelaksanaan fungsi pengawasan ini, BPD berhak meminta pertanggungjawaban kepala desa serta meminta keterangan kepada pemerintah desa. Dengan demikian, pelaksanaan dari fungsi pengawasan yang dilakukan BPD sebagai berikut:

1) Pengawasan terhadap Pelaksanaan

Peraturan Desa

Badan Permusyawaratan Desa (BPD) dalam menjalankan fungsinya yaitu dengan mengawasi segala tindakan yang dilakukan oleh pelaksana peraturan desa. Beberapa cara pengawasan yang dilakukan BPD terhadap pelaksanaan peraturan desa antara lain sebagai berikut:

a) Mengawasi semua tindakan yang dilakukan oleh pelaksana peraturan desa seperti kepala desa, sekretaris desa,dan aparat desa lainnya. 
UNIFIKASI : Jurnal IImu Hukum, Volume 05 Nomor 01, Januari 2018

b) Dalam hal terjadi penyelewengan, biasanya BPD hanya melakukan teguran sehingga untuk menimbulkan reaksi dari BPD untuk melakukan sanksi yang berat tidak ada karena hanya dengan teguran saja itu sudah berhasil.

2) Pengawasan terhadap Anggaran Pendapatan dan Belanja Desa

Pengawasan terhadap Anggaran Pendapatan dan Belanja Desa (APBDes) ini dapat dilihat di dalam laporan pertanggungjawaban Kepala Desa setiap akhir tahun anggaran. Bentuk pengawasan yang dilakukan oleh BPD Desa adalah:

a) Memantau semua pemasukan dan pengeluaran kas desa.

b) Memantau secara rutin mengenai danadana swadaya yang digunakan untuk membangun sarana-sarana umum atau untuk pembangunan desa.

3) Pengawasan terhadap Keputusan Kepala Desa

Kepala desa di dalam melaksanakan pemerintah desa juga berhak untuk membuat keputusan kepala desa. Keputusan kepala desa dibuat untuk mempermudah jalannya peraturan desa. Pengawasan yang dilakukan oleh BPD Desa terhadap keputusan kepala desa yaitu sebagai berikut:

a) Melihat proses pembuatan keputusan dan isi keputusan tersebut.

b) Melihat apakah isi keputusan tersebut sudah sesuai untuk dijadikan pedoman penyusunan RAPBDes.

c) Mengawasi apakah keputusan tersebut benar-benar dijalankan atau tidak.

d) Mengawasi apakah dalam menjalankan keputusan tersebut ada penyelewengan.

e) Menindaklanjuti apabila dalam menjalankan keputusan ada penyelewengan.

Berdasarkan uraian yang telah dipaparkan di atas maka proses pengawasan yang
p-ISSN 2354-5976, e-ISSN 2580-7382

https://journal.uniku.ac.id/index.php/unifikasi

dilakukan Badan Permusyawaratan Desa (BPD) terhadap pemerintahan desa (kepala desa) dapat digambarkan berikut:

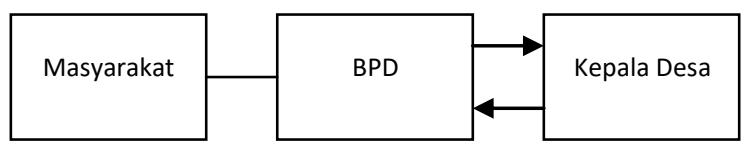

Gambar 1 Proses Pengawasan BPD

\section{SIMPULAN}

Berdasarkan diuraikan analisis dan pembahasan mengenai kewenangan BPD dalam menjalankan fungsi pengawasan terhadap pemerintah desa di Desa Sukaharja dapat ditarik kesimpulan:

a. Kewenangan BPD dalam menjalankan fungsi pengawasan berdasarkan UndangUndang Nomor 6 Tahun 2014 tentang Desa yaitu BPD berhak meminta pertanggungjawaban kepala desa serta meminta keterangan kepada pemerintah desa. Fungsi dalam bidang pengawasan ini meliputi pengawasan terhadap pelaksanaan peraturan desa, pengawasan terhadap Anggaran Pendapatan dan Belanja Desa (APBDes), dan pengawasan terhadap keputusan kepala desa.

b. Faktor-faktor penghambat fungsi pengawasan BPD terhadap Pemerintah Desa terbagi menjadi dua yaitu faktor penghambat internal dan faktor penghambat eksternal. Faktor penghambat internal merupakan faktorfaktor yang menghambat fungsi pengawasan yang berasal dari BPD itu sendiri, meliputi: sarana belum memadai, pola komunikasi tidak berjalan sebagaimana mestinya, dan anggota BPD tidak memahami fungsi. Faktor penghambat eksternal merupakan faktorfaktor yang menghambat fungsi pengawasan yang berasal dari luar BPD, meliputi: masyarakat kurang memahami 
UNIFIKASI : Jurnal IImu Hukum, Volume 05 Nomor 01, Januari 2018

fungsi dari BPD, tidak ada sosialisasi dari pemerintah desa terkait fungsi BPD, dan faktor sumber daya manusia masyarakat desa.

\section{SARAN}

Berdasarkan hal - hal yang telah diuraikan penelitian yang telah dilakukan oleh penulis mengenai kewenangan BPD dalam menjalankan fungsi pengawasan terhadap pemerintah desa di Desa Sukaharja, penulis memberikan saran sebagai berikut:

a. Saran Berkaitan dengan Kewenangan BPD

1) Badan Permusyawaratan Desa (BPD) sebaiknya dapat memperhatikan dan melaksanakan fungsi pengawasan terhadap pemerintah desa berdasarkan Undang-Undang Nomor 6 Tahun 2014 dan mensosialisasikan fungsi BPD kepada masyarakat. Selain itu, BPD diharapkan dapat lebih meningkatkan koordinasi baik sesama anggota BPD dan juga terhadap pemerintah desa terutama kepala desa.

2) Perlunya para anggota BPD diberikan pendidikan dan pelatihan tentang BPD seperti pengenalan lebih dalam tentang tugas BPD, fungsi BPD, dan kewajiban BPD terutama untuk anggota BPD yang baru dilantik. Dengan hal ini akan menambah pengetahuan dan ketrampilan para anggota BPD dalam menjalankan tugas-tugasnya.

3) Pemerintah Kabupaten Kuningan melalui $A P B D$ diharapkan dapat memberikan suplai dana operasionalisasi BPD, dan tunjangan (insentif) untuk kesejahteraan BPD di masing-masing desa yang tersebar di wilayah pemerintahan Kabupaten Kuningan khususnya Desa Sukaharja Kecamatan Cibingbin Kabupaten Kuningan.

b. Saran Untuk Mengatasi Faktor Penghambat Fungsi Pengawasan BPD
p-ISSN 2354-5976, e-ISSN 2580-7382 https://journal.uniku.ac.id/index.php/unifikasi

1) Meningkatkan partisipasi masyarakat, masyarakat merupakan faktor penentu keberhasilan BPD dalam melaksanakan fungsinya, besarnya dukungan dan sambutan serta penghargaan dari masyarakat kepada BPD menjadikan BPD lebih mempunyai ruang gerak untuk dapat melaksanakan fungsinya. Dukungan dari masyarakat tidak hanya pada banyaknya aspirasi yang masuk juga dari pelaksanaan suatu perdes. Kemauan dan semangat dari masyarakatlah yang menjadikan segala keputusan dari BPD dan pemerintah desa menjadi mudah untuk dilaksanakan. Partisipasi masyarakat baik dalam bentuk aspirasi maupun dalam pelaksanaan suatu keputusan sangat menentukan efektivitas tugas dan fungsi BPD. BPD sebagai wadah untuk menampung dan menyalurkan aspirasi masyarakat memerlukan partisipasi masyarakat dalam memberikan dukungan terhadap pelaksanaan tugas dan fungsi BPD. Dengan demikian, meningkatnya partisipasi masyarakat dapat meningkatkan fungsi pengawasan BPD terhadap pemerintah desa.

2) Membangun pola hubungan kerjasama dengan pemerintah desa, salah satu faktor pendukung efektivitas tugas dan fungsi BPD adalah terciptanya hubungan yang harmonis antara BPD dengan pemerintah desa dengan senantiasa menghargai dan menghormati satu sama lain, serta adannya niat baik untuk saling membantu dan saling mengingatkan. Keharmonisan ini disebabkan karena adanya tujuan dan kepentingan bersama yang ingin dicapai yaitu untuk mensejahterakan masyarakat desa. Sebagai unsur yang bermitra dalam penyelenggaraan pemerintahan desa, BPD dan pemerintah desa harus selalu 
UNIFIKASI : Jurnal Ilmu Hukum,

Volume 05 Nomor 01, Januari 2018

menyadari adanya kedudukan yang sejajar antara keduanya.

3) Pemberian insentif kepada BPD, adanya pemberian insentif dari pemerintah memacu kinerja BPD untuk menjadi lebih baik. Walupun bagi anggota BPD insentif tersebut belum memadai namun bagi mereka adanya insentif merupakan wujud penghargaan dan kepedulian pemerintah terhadap BPD.

4) Sistem pemilihan anggota BPD dipilih langsung oleh masyarakat, apabila sistem rekruitmen atau pemilihan anggota BPD menggunakan sistem pemilihan secara langsung oleh masyarakat, maka hal ini menjadikan tingginya kepercayaan masyarakat terhadap orang-orang yang menjadi anggota BPD sehingga kinerjanya dapat tercapai secara baik khususnya dalam melakukan fungsi pengawasan terhadap jalannya pemerintahan desa. Selain itu, sistem pemilihan anggota BPD dapat dilakukan melalui rekrutmen berdasarkan peraturan desa yang berbasis karakteristik desa itu sendiri atau pemilihan anggota BPD didasarkan atas ketokohan atau orang-orang yang pernah aktif di pemerintahan desa

\section{DAFTAR PUSTAKA}

Akhmaddhian, Suwari dan Anthon

Fathanudien. Partisipasi Masyarakat dalam Mewujudkan Kuningan sebagai Kabupaten Konservasi (Studi di Kabupaten Kuningan). Jurnal UNIFIKASI Vol. 2 (1). 2015. DOI: https://doi.org/10.25134/unifikasi.v2i1.26

Akhmaddhian, Suwari. Pengaruh Kebijakan Pemerintah Daerah Dalam Konservasi Sumber Daya Air Terhadap Kesadaran Lingkungan Masyarakat Kabupaten Kuningan, Jurnal Unifikasi, ISSN 2354-5976 Vol. 04 Nomor 01
p-ISSN 2354-5976, e-ISSN 2580-7382

https://journal.uniku.ac.id/index.php/unifikasi

Januari 2017, hlm.

1-13.

https://doi.org/10.25134/unifikasi.v4i1.477

Atmosudirdjo, Prayudi. 1992. Hukum

Administrasi Negara, Jakarta: Ghalia Indonesia.

Mangoto, Karlos. Fungsi Badan

Permusyawaratan Desa (BPD) dalam

Pengawasan Penyelenggaraan

Pemerintahan di Lesah Kecamatan

Tagulandang Kabupaten Kepulauan

Sitaro. Jurnal, Perpustakaan FISIP

UNSRAT Manado, 2016.

Makmur. 2011. Efektifitas Kebijakan

Kelembagaan Pengawasan, Refika

Aditama, Bandung, 2011.

Nugroho, Mohammad Fiqqri Fajar. 2016.

Pengawasan Badan Permusyawaratan

Desa dalam Perencanaan Pembangunan

Desa di Kecamatan Margoyoso

Kabupaten Pati. Skripsi, Fakultas

Syari'ah dan Hukum Universitas Islam

Negeri Sunan Kalijaga Yogyakarta.

Pambudi, Bagus. Peran BPD dalam melaksanakan Fungsi Pengawasan Kepala Desa di Desa Sarimulyo Kecamatan Ngawen Kabupaten Blora, Jurnal, Sumber:

http://www.download.portalgaruda.or

q, diakses 22 Februari 2017.

Rusadi Kantaprawira, Rusadi. Hukum dan

Kekuasaan, Makalah, Universitas

Islam Indonesia, Yogyakarta, 1998.

Sartika Putri Ngadi. Peran Badan Permusyawaratan Desa dalam

Menjalankan Fungsi Pengawasan

Pemerintahan di Desa Lopana

Kecamatan Amurang Timur Kabupaten

Minahasa Selatan, Jurnal,

Perpustakaan FISIP UNSRAT

Manado, 2013.

Yuhandra, Erga. Kewenangan BPD (Badan

Permusyawaratan Desa) Dalam

Menjalankan Fungsi Legislasi, Jurnal 
UNIFIKASI : Jurnal IImu Hukum, Volume 05 Nomor 01, Januari 2018

Unifikasi, ISSN 2354-5976 Vol. 3

No. 2 Juli 2016. Halaman. 61-76.

Undang-Undang Dasar Negara Republik Indonesia Tahun 1945.

Undang-Undang Republik Indonesia Nomor 6 Tahun 2014 tentang Desa.

Undang-Undang Republik Indonesia Nomor 23

Tahun 2014 tentang Pemerintahan Daerah.

Undang-Undang Nomor 9 Tahun 2015 tentang Perubahan Kedua Atas UndangUndang Nomor 23 Tahun 2014 tentang Pemerintahan Daerah.

Peraturan Pemerintah Nomor 72 Tahun 2005 tentang Desa.

Peraturan Pemerintah Nomor 43 Tahun 2014 tentang Peraturan Pelaksana UndangUndang Nomor 6 Tahun 2014.

Peraturan Daerah Kabupaten Kuningan Nomor 11 Tahun 2015 tentang Susunan Organisasi dan Tata Kerja Pemerintahan Desa.
p-ISSN 2354-5976, e-ISSN 2580-7382

https://journal.uniku.ac.id/index.php/unifikasi 